\title{
Payments for ecosystem services in an African protected area: exploring issues of legitimacy, fairness, equity and effectiveness
}

\author{
Nicole D. Gross-Camp, Adrian Martin, Shawn McGuire, Bereket Kebede and \\ JOSEPH MUNYARUKAZA
}

\begin{abstract}
We explore the potential for payments for ecosystem services (PES) to reconcile conservation and development goals, using a case study of an experimental PES intervention around the Nyungwe National Park in Rwanda. The scheme involves the purchase of biodiversity conservation services from local communities in four selected locations. Although a portion of the payment is awarded at the household level, it is the collective action of the community that determines the level of the payment. Contracts are negotiated annually and include performance indicators within each participating community. We examine the ability of PES to achieve conservation and development objectives, through three sub-questions: Is the PES scheme effective? Is it legitimate and fair? Is it equitable? Our findings indicate that the relationship between these evaluation criteria is complex, with both trade-offs and synergies. In this case study the effectiveness of PES is dependent on the equitable distribution of the payment, participants' belief and acceptance of the service being paid for, institutional histories that aid in the establishment of legitimacy and fairness, and the complementary nature of PES to more conventional enforcement methods.
\end{abstract}

Keywords Biodiversity, conservation payments, economic valuation, ecosystem services, ICDPs, Nyungwe National Park, pro-poor conservation, Rwanda

This paper contains supplementary material that can be found online at http://journals.cambridge.org

\section{Introduction}

D iodiversity is unevenly distributed, with some of the Bhighest concentrations in the tropics (Gaston, 2000). Such biodiversity is thought to support human well-being by providing the medium for energy and material flows that underpin ecosystem services (Myers, 1997) but adjacent to

Nicole D. Gross-Camp (Corresponding author), Adrian Martin, Shawn McGuire, Bereket Kebede and Joseph Munyarukaza International Development UEA, University of East Anglia, Norwich, NR4 7TJ, UK. E-mail n.gross-camp@uea.ac.uk

Received 9 February 2011. Revision requested 27 May 2011.

Accepted 18 July 2011. this biological wealth live some of the world's poorest people who often rely on environmental resources to provide a substantial proportion of their household income (Cavendish, 2000). The overlap of areas with high biodiversity and human poverty is well established (Wells, 1992; Fisher \& Christopher, 2007; Holland et al., 2009) but how to simultaneously protect biodiversity and reduce poverty remains unclear (Adams et al., 2004).

Integrated conservation and development projects (ICDPs) have been a popular way of addressing concerns for biodiversity conservation and poverty reduction but the performance of such programmes has been mixed, with a fundamental criticism being the failure of incentive structures to link conservation outcomes and development initiatives directly (Salafsky \& Wollenberg, 2000; Martin et al., 2011). ICDPs often assume an inverse relationship between income and the collection of forest resources, an assumption that contradicts some empirical research (Cavendish, 2000). In contrast, making a payment contingent upon conservation performance may effectively incentivize conservation-oriented behaviour (Ferraro \& Kiss, 2002). Such payments for ecosystem services (PES), in which a service provider is awarded a payment contingent upon service delivery to a service user (Wunder, 2007), is an increasingly common approach. Initial theoretical studies support the promise of PES to be more cost efficient than indirect approaches to conservation (Ferraro \& Simpson, 2005). However, theory needs to be informed through learning-by-doing in real world contexts.

PES interventions in developing countries face particular challenges arising from a high incidence of poverty, variable or insecure rights to land, and heavy reliance on collection of natural resources for subsistence. In addition, many areas believed to provide high levels of ecosystem service provision are often state-owned, with communities having only customary rights of access, or being strictly excluded, as in the case of many National Park systems. PES projects do not in general pay individuals for obeying the law (Sommerville et al., 2010b) yet such payments may enable poorer communities to engage in strategies that reduce their reliance on resource collection from protected areas (Bruner et al., 2001) and more fairly distribute the burden of costs arising from expanded protected area networks. Whilst there has been a recent proliferation of research on PES there remains a gap in empirical evaluations that assess the 
ability of contingent payments to address conservation and development objectives simultaneously. Our experimental PES project, Reconciling Biodiversity and Development through Direct Payments for Conservation (hereafter, ReDirect), was established to help narrow this gap by empirically evaluating the ability of PES to achieve these goals in a high biodiversity, low income, protected area setting.

Here we explore whether PES can offer a viable approach to reconciling conservation and development in an African protected area. We address this through three subquestions: Is the PES scheme effective? Is it legitimate and fair? Is it equitable? We define effectiveness as delivery of defined ecosystem services and the co-benefit of livelihood support. In the case of ReDirect biodiversity protection is the target service, defined by the indicator of human activities that threaten biodiversity; livelihood impacts are measured through surveys of multiple dimensions of poverty. Legitimacy refers to stakeholder perceptions about how PES conforms to formal and informal rules and norms with respect to both the general design of PES and the procedures of decision making. This is examined from the perspective of participating communities and key implementation partners, namely local authorities and the Rwandan Development Board, Tourism \& Conservation (RDB). Implementing partners tend to view legitimacy in relation to narratives of sustainability: the available funding stream for payments as well as the durability of livelihood assets arising from cash payments. We define legitimacy based on a stakeholder's ability to negotiate outcomes from the PES contract. In particular we are interested in determining whether participants consider the negotiation outcome satisfactory; i.e. were their individual interests accurately and sufficiently represented in the contract negotiation process? We ask whether the project is fair in the sense that what is given up (collection of resources in Nyungwe National Park) is worth the payment received in exchange. Finally, we examine equity in terms of how individual households benefit or lose from our PES intervention and the impacts of the project on more vulnerable groups. For example, although all households gain up to USD 30 per year, some households may be less able to cope with the corresponding reduction in use of forest products. We are interested in examining whether and how communities recognize inequity in the PES intervention and whether communities autonomously make any concessions towards such differences.

\section{Study area}

The $1,013-\mathrm{km}^{2}$ Nyungwe National Park is in the Albertine Rift, an area recognized for its high biodiversity and endemism (Plumptre et al., 2002). Connecting with the
Kibira National Park in Burundi, Nyungwe National Park forms one of the largest contiguous blocks of lower montane forests in Africa (Vedder et al., 1992). Although the Park was only established in March 2004 it was first gazetted as a forest reserve by Belgian colonialists in the early $1930 \mathrm{~s}$ (Masozera, 2002). Prior to gaining National Park status, clearing of the forest for agriculture was prohibited but local rights to collect wood were recognized and upheld in 1969 with the initiation of a buffer zone of fast-growing exotics both to help protect the forest core by demarcating boundaries and provide a long-term source of wood for local communities (Weber, 1989).

Rule enforcement was poor up until the late 1980 s when the RDB was first mandated to improve this (Masozera, 2002) and when the Wildlife Conservation Society became active in the reserve. The work of both organizations was suspended during the 1994 genocide but they remain the main conservation and management authorities in the Park. Buffer zone management resides with a third organization, the National Forestry Association and, although the RDB has no formal authority or responsibility, it remains a de facto manager.

An important feature of ReDirect is its focus on a public resource where natural resource collection is legally prohibited. Because the public good is already protected (at least legally) some people may challenge our focus on such a resource and question the ability of PES to improve significantly the levels of protection already established (additionality). Although the ability of PES to improve conservation efforts in areas where strict reinforcement occurs is valid, enforcement alone is often insufficient. We wished to examine the complementarity of PES to more traditional enforcement methods. Furthermore the benefits of protected areas tend to be more broadly (i.e. globally) distributed whereas the burdens accrue locally. In developing countries such burdens are most often carried by poorer communities living adjacent to protected areas (Balmford \& Whitten, 2003; Adams et al., 2004); PES may be a way to help 'level the playing field' by distributing the costs and benefits of conservation more equally. A second distinguishing feature of ReDirect is the collective responsibility for service provision (see also Sommerville et al., 2010a,b). Although a portion of the annual payment is made at the household level it is the collective action of the community that determines the actual payment amount. Dependence on collective action is complicated by the uneven distribution of opportunity costs within communities, providing a possible opportunity for 'free-riding'; a common problem for public good management (Ostrom, 1990; Agrawal, 2001).

The unit of participation is the cell, the smallest administrative unit in Rwanda, made up of three to six villages. We selected four participating cells adjacent to Nyungwe National Park, with paired controls (Table 1). Only cells located south of the main road (Fig. 1) were 
TABLE 1 Demographics of the four participating (P) cells and paired control cells, with the number of households per cell, mean annual household consumption calculated from the livelihood surveys, percentage of household consumption from forest resources and estimated opportunity costs based on this consumption. The opportunity costs exceed the annual household award of USD 30 in all but one cell. No households reported use of forest resources in Murwa.

\begin{tabular}{|c|c|c|c|c|}
\hline Cell name & $\begin{array}{l}\text { No. of } \\
\text { households }\end{array}$ & $\begin{array}{l}\text { Mean annual } \\
\text { consumption } \pm \\
\text { SE (USD) }\end{array}$ & $\begin{array}{l}\% \text { of } \\
\text { consumption } \\
\text { from forest } \\
\text { resources }\end{array}$ & $\begin{array}{l}\text { Opportunity } \\
\text { cost (USD) }\end{array}$ \\
\hline Gahurizo (P) & 1,002 & $512 \pm 133$ & $18(1)$ & 92 \\
\hline Rukore & 727 & $588 \pm 216$ & $3(2)$ & 18 \\
\hline Shaba (P) & 1,132 & $1,651 \pm 648$ & $6(8)$ & 99 \\
\hline Kagano & 1,020 & $1,470 \pm 422$ & $7(8)$ & 103 \\
\hline Murwa (P) & 295 & $792 \pm 269$ & & \\
\hline Kiyabo & 761 & $1,209 \pm 590$ & $33(1)$ & 399 \\
\hline Uwumusebeya (P) & 930 & $881 \pm 294$ & $21(12)$ & 185 \\
\hline Ruyenzi & 932 & $902 \pm 336$ & $22(11)$ & 198 \\
\hline
\end{tabular}

included in the selection process, to reduce logistical constraints. Three cells were randomly selected, with the fourth, Uwumusebeya, being explicitly included based on expressed interest from the RDB. The forest adjacent to the Uwumusebeya cell contains the largest bamboo Yushania alpina ecosystem (3,174 ha) in the Park and is home to a rare endemic primate, the owl-faced monkey Cercopithecus hamlynii. The local communities in this area utilize bamboo for a variety of purposes, including construction, baskets, mats and snares. Control cells were located adjacent to participating cells in an effort to capture leakage, displacement of human activities from participating cells, and to investigate the impact of PES on non-participating communities.

\section{Methods}

\section{PES design}

The level of payment per household was based on estimated opportunity costs (foregone income) from providing the required service, namely a reduction in forest resource collection. We based this estimate on Masozera \& Alvapati (2004), who calculated the average annual forest-based income for a household living near Nyungwe National Park to be USD 30 (range: USD 2-76). Two annual cash payments were or will be awarded (in January 2011 and 2012) based on performance in relation to conditions outlined in the contract. An initial goodwill payment ( $1 / 3$ of the maximum amount) was disbursed to each cell in April 2010 and was intended to enable communities to invest in activities that would help them adhere to the contract conditions. The goodwill payments were also helpful in determining the logistics of the cash transfer process. Money was transferred to bank accounts of the cell administration, where it was further distributed into newly established local bank accounts, Savings \& Credit Cooperatives, for each household.

The PES targets biodiversity conservation that is monitored by the level of illicit human activities in the Park. We selected six human activities that are easily observable and quantifiable over short periods of time (3-4 months): wood cutting, bamboo cutting, snare presence, mining for minerals, beehives (associated with cutting of large trees, and fires, for honey collection) and new forest trails. These activities constitute the major threats to biodiversity observed by the RDB's ranger-based monitoring system (Mulindahabi \& Ndikubwimana, 2010). We also monitored and rewarded activities outside the Park that are believed to support conservation, namely the organization of committees to reduce the problem of cropraiding, tree and bamboo planting, and regular communication with, and assistance of, the RDB.

\section{Data collection}

Livelihood surveys were conducted in 12 cells around the Park, including the eight participating and control cells of ReDirect (Appendix 1). Forty-eight households per cell $(n=576)$ were randomly selected from a list of households. A baseline survey was conducted in September 2009 and the same households will be re-surveyed at the end of the study in early 2012. These surveys addressed the development outcomes of the PES and included data on forest resource use, household assets and consumption expenditures. We used surveys to calculate a household's consumption as an indication of wealth and, more specifically, to determine whether cells differed significantly in their consumption expenditures (i.e. issues of equity). Household consumption was determined by totalling the value of items consumed from the Park (as an indication of opportunity costs), food items, durable goods (i.e. 


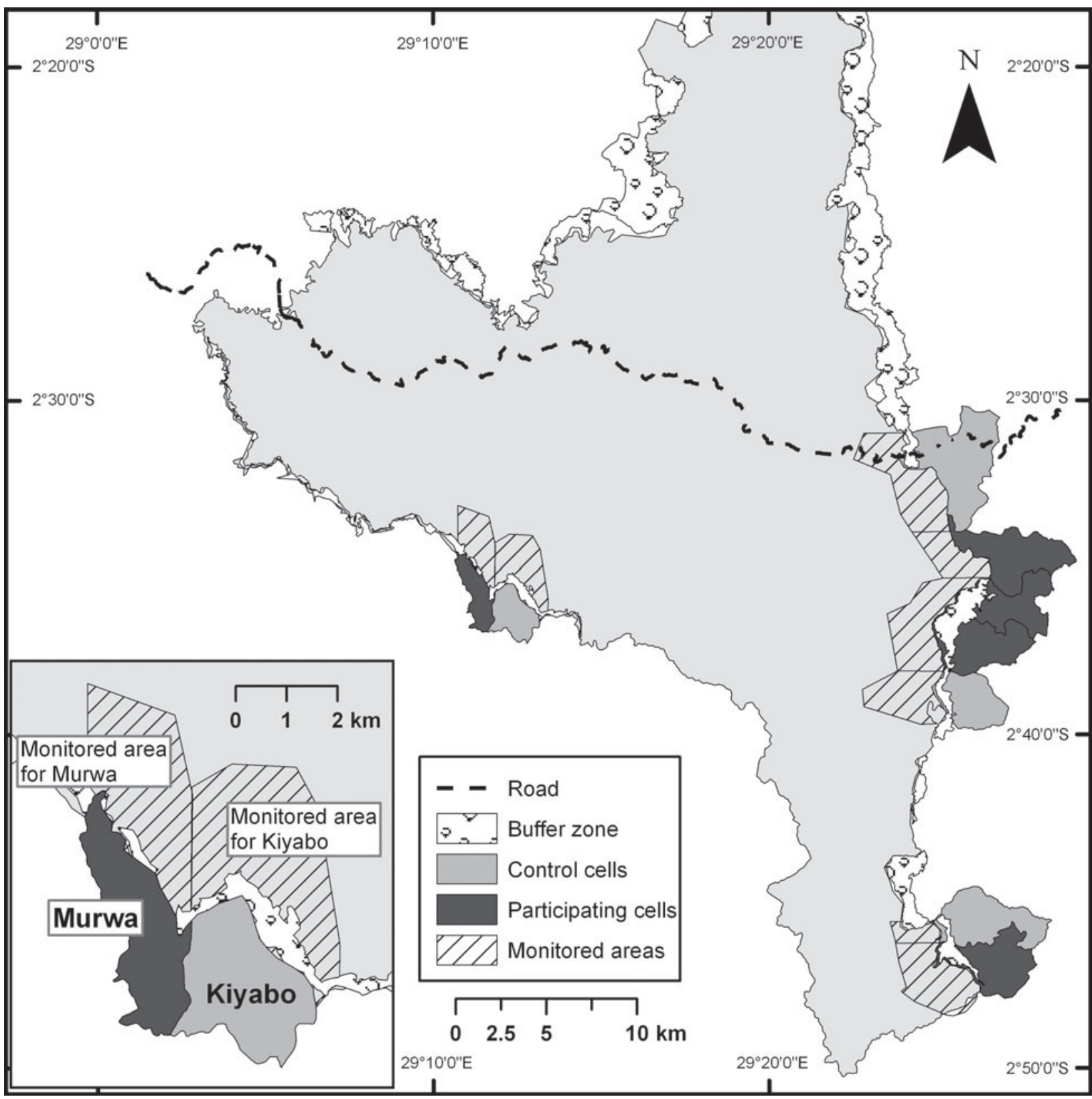

FIG. 1 Nyungwe National Park in Rwanda, showing participating and control cells and the buffer zone (see text for details). The inset shows a close up of one paired cell group and the corresponding monitored areas. The size of the monitored area depends on the length of a cell's perimeter with the Park: $2.5 \mathrm{~km}$ perpendicular lines from the edge of a cell's boundaries demarcated the monitored area.

bicycles, radios), social events such as weddings or funerals, and educational expenses by a given household on an annual basis. Mean market value for items was established through a series of four price surveys conducted in markets in or close to the cells where interviews took place.

Livelihood surveys were also used to examine whether participants viewed the services received from the Park as beneficial, whether the implementation of the PES scheme had any impact on their resource use, and finally whether such a change in resource use affected their livelihoods, either positively or negatively. Our method was intended to capture potential and perceived impacts to guide more empirical investigation (i.e. socio-economic surveys) further along in the study.

Human activity in the Park was measured as an encounter rate (signs of activities per $\mathrm{km}$ walked) by walking the existing trail system within a defined subsection of the Park for each cell. The existing trail system was geo-referenced using a global positioning system and followed during subsequent surveys. The length of trail varied according to the size of the cell $(2.8-29.3 \mathrm{~km})$. We opted to follow the existing trail system, as opposed to 
establishing randomized transects, based on our interest in capturing human activity and prior difficulty experienced by the Wildlife Conservation Society in capturing human activity using randomized methods. The baseline survey in November 2009 helped to identify the principal activities to be monitored and established the reference against which performance is to be judged. Trails were walked at a rate of $1 \mathrm{~km} \mathrm{~h}^{-1}$ and repeated every 4 months over the course of the year ( 3 surveys per year). The monitored area was defined by drawing perpendicular lines $2.5 \mathrm{~km}$ from the edge of the cell boundary into the Park (Fig. 1) using ArcGIS v. 9.3 (ESRI, Redlands, USA). Any of the six human activities observed in the area between the two lines was counted against the cell. However, only snares, bamboo or wood cutting, and beehives were included in the calculation of the encounter rate of signs of activities. Mining and new trails were considered higher level threats and assigned a financial penalty for each observation.

The distance of $2.5 \mathrm{~km}$ was chosen based on the finding that the majority of human activity occurs within $1.5 \mathrm{~km}$ of protected area boundaries and sharply declines at a distance greater than $5 \mathrm{~km}$ (Waas, 1995). Ranger-based monitoring data collected by the RDB in 2010 supports this, having found the highest concentration of human activity within 2-3 km of the Park's boundaries (Mulindahabi \& Ndikubwimana, 2010). Our study design is such that participating cells are responsible for protecting their section of the Park from people within as well as from outside the cell. During initial community-wide meetings with ReDirect, cell representatives expressed concern over this issue and in particular how to deal with the potential for outsiders to affect the level of human activity within a cell's given area of the Park. ReDirect encourages reporting of illicit activities to the management authorities but also acknowledges the limitations of our study design: all activities within the defined boundaries of a participating cell count against the cell regardless of who did the activity. We intentionally placed our control cells adjacent to participating cells in an effort to capture leakage of participating cells (i.e. into adjacent control cells) but detecting outside activity within a participating cell remains difficult.

Payments to cells are based on a series of performance indicators established in an annually reviewed contract between a given cell and the project. Payment begins at 50\% of the maximum possible payment and is then increased or decreased (down to a potential payment of zero) based on a cell's achievement of the defined indicators (Appendix 2). Performance indicators include level of human activity in relation to the baseline, cell awareness of project basics (i.e. conditionality), assistance to the Park management authorities, and number of tree and bamboo culms planted.

Monitoring for illicit activity and positive collective actions was also undertaken through community monitors affiliated with ReDirect. Community monitors were selected by their respective cells (4-6 monitors per cell) and serve as liaisons between their cells and the project, maintaining log books that detail specific events such as encounters with hunters, the number and location of trees planted, location and severity of crop-raiding events, and details of meetings in which the project is discussed.

Social impacts have been monitored through focus group discussions $(n=20)$, semi-structured interviews $(n=34$ analysed to date), and community monitor logs in each cell (4-6 logs per cell; $n=19$ ). We also include the findings from additional interviews conducted in Uwumusebeya cell $(n=24)$ to help evaluate the ability of PES to be pro-poor. We refer to pro-poor in both the weak sense of not harming the poor and in the strong sense of the poor gaining more relative to the non-poor. Uwumusebeya was purposefully targeted based on the fact that households there have higher opportunity costs because of greater dependence on forest products. We were interested in exploring how more vulnerable groups such as those in Uwumusebeya are affected by the PES intervention. Furthermore this cell was selected based on the greater difficulties between Uwumusebeya and the RDB authorities.

\section{Results}

\section{Is PES effective?}

Although the baseline encounter rate did not differ significantly from that after the PES intervention (mean $3.40 \pm 3.23$ SD and $1.75 \pm 1.41$, respectively; paired $t(7)=1.33$, $\mathrm{P}=0.22$; Fig. 2) the values suggest a decrease in human activity after the PES implementation for all but two cells, one participating and one control. Similarly a multivariate repeated measures model between participating and control cells and within-cell pre- and post-PES implementation was not significant $\left(\mathrm{F}_{1,8}=0.13, \mathrm{P}=0.73\right.$; range of encounter rate pre- and post-PES: $0.8-10.7$ and $0.5-3.3$, respectively, in participating cells versus 1.1-4.4 and 0.3-3.1 in control cells).

In interviews few households admitted to illicit forest use, although some described how they had recently stopped collecting wood, mining, or hunting in the Park and buffer zone. Such claims are hard to assess on their own but a general sense of decreased forest use is shared by the RDB. This gains further credence from the increased frequency of community meetings since the start of the project to promote the importance of conservation, and the increased intensity of monitoring. Although interviews suggested that arrests were uncommon, there were frequent reports of poachers or collectors of forest products being reprimanded. The project has stimulated a wide range of community members to be involved in reporting or disrupting illicit activities, which appears to have increased deterrence. 


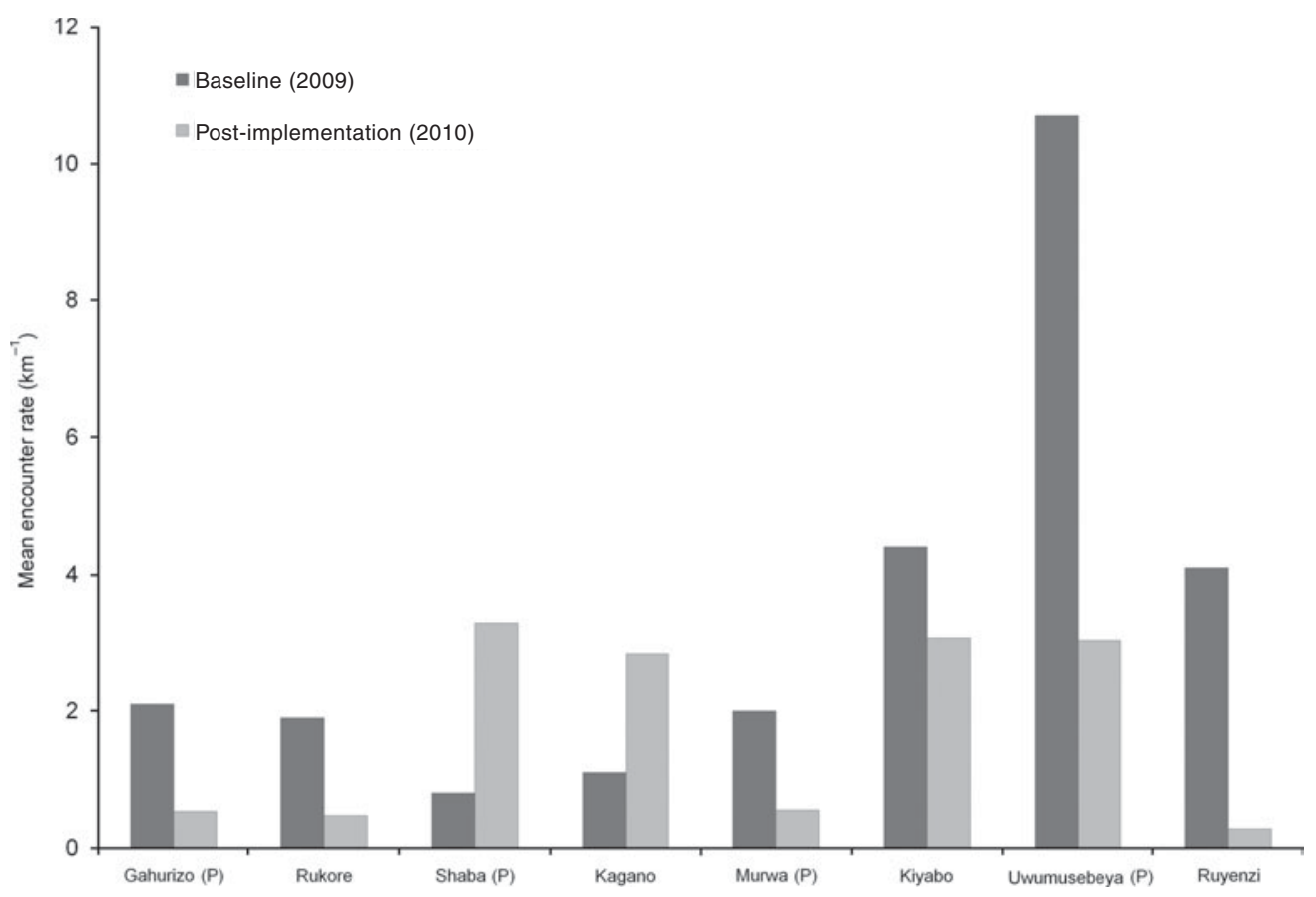

FIG. 2 Mean encounter rate of human activity per $\mathrm{km}$ walked in each pair of participating $(\mathrm{P})$ and control cells. There was no statistical significance between pre- (2009) and post- (2010) implementation of the PES scheme despite a notable decrease in encounter rates.
Our evidence for the effectiveness of the PES in supporting livelihoods is based on a combination of household perceptions of the benefits of forest conservation, reported changes in resource use behaviour, and expected livelihood impacts. All respondents in the livelihoods survey indicated that the Park is worth protecting, with the main reasons being the benefits to local climate $(64 \%$ of respondents mentioned rainfall effects) and benefits for biodiversity and tourism income (23\% mentioned both). Households reported several behavioural changes as a result of the PES scheme, including tree or bamboo planting, grass planting to reduce the need for forest collection, the formation of cooperatives to guard against crop-raiding, purchase of plantation firewood instead of collecting it from the Park or buffer zone, and informing other villagers about the scheme. A few households reported that actions have caused some difficulties because of the increased effort needed for firewood collection or absence of alternative sources. Reports of tree planting was corroborated through examination of community monitoring log book entries and selective verification.

Nearly all respondents suggested ways in which they believed the PES scheme would benefit local livelihoods. In contrast, all but one respondent claimed there were no ways in which it could harm livelihoods (the single exception cited possible increases in crop-raiding). The expected benefits are diverse, with the most frequently cited being the purchase of livestock, which contribute to nutrition, reduce dependence on bushmeat and produce fertiliser for agricultural fields. Other expected benefits include tree planting, farming inputs, medical insurance and housing. Housing improvements were important to some because of concerns about meeting national policies on construction standards (natural roofing is being eliminated by government decree) and house location. In addition to direct impacts on livelihoods arising from cash payments, a majority of respondents expected (1) improved relationships with local government authorities, by helping with these policies as well as requirements to open local bank accounts, (2) improved relationships within the community, as a result of collective activities and reduced sources of conflict, and (3) improved relations with the Park management authorities. Respondents further indicated that the scheme would contribute to conservation by creating resource alternatives and general sensitization of the population to conservation activities.

\section{Is it legitimate and fair?}

We explored the question of legitimacy through the views of three stakeholder groups: the RDB, local government and participating communities. During consultations with the RDB three principal concerns were raised about the legitimacy of PES as an approach to conservation in Rwanda. Firstly, concern about the impact of cash payments in poor rural locations, including fears that money might be poorly used, for example on alcohol. The RDB preferred an ICDP-type approach in which rewards come in the form of development projects, such as a tree nursery. On this particular issue we did not compromise and effectively cashed in the trust established through previous partnership: we asked and were granted permission to give cash payments a chance. On the other hand, we agreed to consult with communities about a potential balance between 
payments to individual households and payments to the community. This led to variation in the balance between household and community payments, with one cell choosing to invest $80 \%$ of all payments in collective activities, and the others 10-30\%. Secondly, the RDB had concerns about rewarding people for not breaking the law. Partly in response to this concern about perverse incentives we opted for an equal payment for all households, as opposed to payment linked to the level of opportunity cost (which is directly related to level of illicit activity). Thirdly, the RDB were concerned about the short-term nature of research funding and the lack of sustainability of the PES scheme. Finding a sustainable approach to financing thus became an additional objective of the project, with time set aside in our mid-project review for pursuing ways to continue beyond the life of ReDirect's funding. We also consider the partnership with the RDB as an initial step towards sustainability. The RDB will continue to operate long after the project has ended; their involvement in ReDirect's experimental design and day-to-day operation will probably increase the impact of communal initiatives beyond the life of the project.

Local authorities were consulted at district, sector and cell levels. With the RDB as a partner these consultations proved straightforward. The legitimacy of the project was largely understood in terms of alignment of development interventions with priorities contained in District Development Plans. For example, we found mutual advantage in the opening of local bank accounts for all households in participating cells; for us it solved the problem of how to disperse cash payments and it enabled local government to be at the vanguard of meeting a national policy target.

In exploring the question of legitimacy with communities we concentrated on the legitimacy of decision-making procedures and the fairness of the resultant scheme design. ReDirect is heavily dependent on consultation activities organized by communities because consent is through representation: a small number of community representatives interact directly with ReDirect staff to give consent for participation by all. With few exceptions those interviewed expressed positive attitudes towards the initial consultation process, stating that all groups were represented and that outcomes reflected the majority. The main exception involved questions about whether particular interests were heard, including those who opposed opening of local bank accounts, which incurs set up fees (6-8 USD). Whilst still mainly positive, a larger proportion of respondents were concerned about decisions by the community representatives regarding how to spend monies. Overall, respondents agreed that the PES scheme was fair, with the key reasons being that all households will be rewarded, all will receive the same, it will enable people to obtain things they could not afford (e.g. medical insurance), and because forest conservation is good for the entire community. Only four respondents raised concerns about fairness, two of these referred to the level of payments not being high enough, the other two had concerns that some may benefit more than others.

\section{Is it equitable?}

We found no significant difference between annual household consumption across all cells (range USD $512 \pm \mathrm{SD} 133$ to $1,651 \pm 648 ;$ ANOVA: $\mathrm{F}_{7,383}=1.49$, $\mathrm{P}=0.17$ ), suggesting that household wealth is relatively uniform in the study area. Forty-three households (11.2\%) from seven cells reported some collection of forest products. When collection was reported, the proportion of a household's consumption coming from forest products was $3-33 \%$, the equivalent of which exceeds our payment of USD 30 for all but one cell (Table 1).

As reported above, the main round of household interviews did not reveal any reports of livelihood harm. Additional interviews in Uwumusebeya cell $(n=24)$ purposefully sought those living closest to the Park, including bamboo users. Most of these respondents expected the PES to affect their livelihoods negatively. Bamboo collectors and basket makers were generally unhappy with the project, with c. $50 \%$ of respondents considering it unfair.

\section{Discussion}

Although not statistically significant there was a noticeable reduction in the level of human activity in the monitored areas of both participating and control cells after implementation of the PES scheme. Whilst it is possible that this may be attributed to multiple factors (e.g. increased presence of management staff or annual variation in resource collection), we believe it is most likely a result of the implementation of PES. Despite receiving no payments control cells interacted with ReDirect staff through initial community meetings and through the collection of semistructured interviews. We suspect that the reduction observed in control cells is in part because of their hope that ReDirect will be expanded into their cells in the future, as has been conveyed by some RDB staff. We cannot claim a clear success in reducing human activities in the Park but still consider the observed pattern to be generally supportive of PES's effectiveness for conservation. A second year of data on encounter rates of human activity in the Park will help to clarify PES's role in reducing such activity. We have also expanded our data collection to include an additional cell that has had no formal contact with ReDirect, to assist in this endeavour. 
One of the major limitations in trying to assess opportunity costs of illegally collected products is that households are not open in describing any such use. It is therefore likely that previous, as well as our own, calculations of opportunity costs are underestimates. The fact that participants (at least in three cells) embrace a PES scheme that probably pays too little for the service provided, and that service providers (mostly) perceive this to be fair is contrary to our expectations. We consider five potential reasons for this conundrum of low payment-high acceptance.

Previous research has found that effectiveness of a PES scheme is not purely a matter of economic incentives (McAfee \& Shapiro, 2010), as evidenced by examples where payments were too low to cover opportunity costs (Kosoy et al., 2007; Fisher, 2012). Participation and results can be as much about the ability to mobilize collective action (Bulte et al., 2008), which may rest on perceived fairness, as about conventional economic analysis or institutional capacity. Our data suggest that perceptions of fairness arise more from the equity of distribution of payments than the level of payments. However, perceptions of fairness also appear to be strongly linked to views about the legitimacy of the commissioned service: a belief that the payment is for doing something intrinsically good such as protecting the forest. Hall (2008) notes that PES systems rely on legitimacy, including laws and beliefs relating to what services a state should be providing. Our data provide some support for this at the state level as well as in terms of the willingness of local participants to engage. We speculate that institutional histories play an important role wherein local receptivity to a forest conservation agenda has been enhanced by longterm sensitization activities led by the RDB and the Wildlife Conservation Society. The involvement of local institutions has been similarly suggested to play an important role in other payment schemes (Petheram \& Campbell, 2010; Stainback \& Masozera, 2010). Another factor that helps to explain the effectiveness of low payments is simply that this PES operates in a National Park. Sommerville et al. (2010a,b) speculate that illegality heightens the motivational power of fear and monitoring, thereby decreasing the necessary payment size. Finally, it is possible that a low payment is augmented by other non-monetary benefits; i.e. community organization and improved relations with management authorities, as has been seen in other PES projects (Kosoy et al., 2008; Wunder \& Alban, 2008) and to which our data lend limited support.

The above discussion largely supports the view that effectiveness in a development sense is positively related to perceptions of legitimacy and fairness. Nevertheless, we should also expect trade-offs. We found that household consumption does not vary significantly between cells but that dependence on forest resources does and, therefore, so do opportunity costs. In addition to differences in resource use between cells there are also particular households with greater costs arising from the PES intervention. However, given the particular context of ReDirect, we found that the potential risks arising from a single payment level must be balanced against the benefits for legitimacy: from the perspective of both our partners and the communities. We have some evidence that this trade-off may be affecting the ability of Uwumusebeya to achieve agreed contract conditions.

The challenge that we face in this cell is partly the tradeoff between project legitimacy, and equity and effectiveness; i.e. the single payment level does not offset opportunity costs. However, perceptions of ReDirect have also probably been influenced by a number of historical events, including evictions from the forest 20 years ago, recent events arising within the project, including unforeseen transaction costs of opening local bank accounts, and events beyond the project such as the killing of a bamboo collector by a Burundian soldier, the RDB's restriction on grass collection from the buffer zone, and national housing policy eliminating the use of bamboo for roofing.

Clearly the challenges faced by PES in Uwumusebeya are based on a broad set of factors. On the other hand the community monitors state that local attitudes are starting to see forest use more as an illicit activity and this may help explain why even those losing income because of greater restrictions on access to forest resources often accept the project restrictions on bamboo use. Uwumusebeya has introduced pro-poor elements, including provision of livestock to the poorest, although those making the most money from bamboo are unlikely to be the poorest, suggesting pro-poor may not always directly serve conservation effectiveness. Other cells have similarly demonstrated pro-poor activities with collective monies. For example, Shaba cell has distributed 63 goats to the poorest households. Although the benefits of livestock are initiated in the poorest households, norms about the distribution of offspring mean that all house communities in the cell expect to receive an animal at some time. Continuing the donation of animals beyond the poorest households may also be considered as evidence of the interest of the communities in achieving legitimacy and fairness for all members and eventually equity, which tends to be locally interpreted in terms of everyone receiving equally.

Our preliminary evaluation of ReDirect suggests mixed support for the ability of PES to address conservation and development objectives near protected areas. The main conservation metric, encounter rate of human activity, did not significantly differ between participating and control cells and yet showed decreasing human activity in most cells, possibly as a result of increased management presence, annual variation in resource collection or the PES scheme itself. Our findings remain limited in their connection to securing service provision but emphasize the importance 
of institutional involvement, and community members, in establishing legitimacy and fairness. Although equity does not appear to be a limiting factor in ReDirect, it would probably require greater consideration at larger scales, where inequity may be more dramatic. The framework that we have developed here to evaluate PES schemes could be applied in other schemes to obtain greater insight into the interplay of legitimacy and fairness, equity, and effectiveness and, in particular, the point at which effectiveness is compromised.

\section{Acknowledgements}

ReDirect is funded through the EU FP7 European Research Council. The project partners are the RDB, the Wildlife Conservation Society Rwanda and the National University of Rwanda. We acknowledge in particular the support of the RDB Chief Park Warden L. Rugerinyange, Head of Law Enforcement P. Nzamuye, and RDB Community Conservation Wardens N. Karegire, E. Musabyimana and R. Hategekimana. We thank JPG Jones and one anonymous reviewer for comments that greatly improved our manuscript.

\section{References}

Adams, W.M., Aveling, R., Brockington, D., Dickson, B., Elliott, J., Hutton, J. et al. (2004) Biodiversity conservation and the eradication of poverty. Science, 306, 1146-1149.

Agrawal, A. (2001) Common property institutions and sustainable governance of resources. World Development, 29, 1649-1672.

Balmford, A. \& Whitten, T. (2003) Who should pay for tropical conservation, and how could the costs be met? Oryx, 37, 238-250.

Bruner, A.G., Gullison, R.E., Rice, R.E. \& da Fonseca, G.A.B. (2001) Effectiveness of parks in protecting tropical biodiversity. Science, 291, 125-128.

Bulte, E., Lipper, L., Stringer, R. \& Zilberman, D. (2008) Payments for ecosystem services and poverty reduction: concepts, issues, and empirical perspectives. Environment and Development Economics, 13, 245-254.

Cavendish, W. (2000) Empirical regularities in the poverty-environment relationship of rural households: evidence from Zimbabwe. World Development, 28, 1979-2003.

Ferraro, P.J. \& Kiss, A. (2002) Direct payments to conserve biodiversity. Science, 298, 1718-1719.

Ferraro, P. \& Simpson, R.D. (2005) Cost-effective conservation when eco-entrepreneurs have market power. Environment and Development Economics, 10, 651-663.

Fisher, B. \& Christopher, T. (2007) Poverty and biodiversity: measuring the overlap of human poverty and the biodiversity hotspots. Ecological Economics, 62, 93-101.

Fisher, J. (2012) No pay, no care? The importance of payments in payments for ecosystem services. Oryx, 46, 45-54.

GASTON, K.J. (2000) Global patterns in biodiversity. Nature, 405, 220-227.

Hall, A. (2008) Better REDD than dead: paying the people for environmental services in Amazonia. Philosophical Transactions of the Royal Society B, 363, 1925-1932.
Holland, T.G., Peterson, G.D. \& Gonzalez, A. (2009) A cross-national analysis of how economic inequality predicts biodiversity loss. Conservation Biology, 23, 1304-1313.

Kosoy, N., Corbera, E. \& Brown, K. (2008) Participation in payments for ecosystem services: case studies from the Lacandon rainforest, Mexico. Geoforum, 39, 2073-2083.

Kosoy, N., Martinez-Tuna, M., Muradian, R. \& MartineZ-Alier, J. (2007) Payments for environmental services in watersheds: insights from a comparative study of three cases in Central America. Ecological Economics, 61, 446-455.

Martin, A., Rutagarama, E., Gray, M., Asuma, S., Bana, M., Basabose, A. \& Mwine, M. (2011) Linking development interventions to conservation: perspectives from partners in the International Gorilla Conservation Programme. Society and Natural Resources, 24, 626-636.

MASOZERA, M.K. (2002) Socio-economic impact analysis of the conservation of the Nyungwe Forest Reserve, Rwanda. MSc thesis, University of Florida, Gainesville, USA.

Masozera, M.K. \& Alavalpati, J.R.R. (2004) Forest dependency and its implications for protected areas management: a case study from the Nyungwe Forest Reserve, Rwanda. Scandinavian Journal of Forest Research, 19, 1-8.

McAfee, K. \& Shapiro, E.N. (2010) Payments for ecosystem services in Mexico: nature, neoliberalism, social movements, and the State. Annals of the Association of American Geographers, 100, 579-599.

Mulindahabi, F. \& Ndikubwimana, I. (2010) Monitoring Threats to Biodiversity in Nyungwe National Park, Rwanda. Ranger-based Monitoring Report Year 2010. Wildlife Conservation Society Rwanda and Rwandan Development Board Tourism \& Conservation, Kigali, Rwanda.

Myers, N. (1997) Environmental services of biodiversity. Proceedings of the National Academy of Sciences of the USA, 93, 2764-2769.

Ostrom, E. (1990) Governing the Commons: The Evolution of Institutions for Collective Action. Cambridge University Press, Cambridge, UK.

Petheram, L. \& Campbell, B.M. (2010) Listening to locals on payments for environmental services. Journal of Environmental Management, 91, 1139-1149.

Plumptre, A.J., Masozera, M., Fashing, P.J., McNeilage, A., Ewango, C., Kaplin, B.A. \& Liengola, I. (2002) Biodiversity Surveys of the Nyungwe Forest of Southwest Rwanda: Final Report. Wildlife Conservation Society, Bronx, USA.

Rodrigues, A.S.L., Andelman, S.J., Bakarr, M.I., Boitani, L., Brooks, T.M., Cowling, R.M. et al. (2004) Effectiveness of the global protected area network in representing species diversity. Nature, 428, 640-643.

Salafsky, N. \& Wollenberg, E. (2000) Linking livelihoods and conservation: a conceptual framework and scale for assessing the integration of human needs and biodiversity. World Development, $28,1421-1438$.

Sommerville, M., Jones, J.P.G., Rahajaharison, M. \& Milner-Gulland, E.J. (2010a) The role of fairness and benefit distribution in community-based payments for environmental services interventions: a case study from Menabe, Madagascar. Ecological Economics, 69, 1262-1271.

Sommerville, M., Milner-Gulland, E.J., Rahajaharison, M. \& JonES, J.P.G. (2010b) Impact of a community-based payment for environmental services intervention on forest use in Menabe, Madagascar. Conservation Biology, 24, 1488-1498.

Stainback, G.A. \& Masozera, M. (2010) Payment for ecosystem services and poverty reduction in Rwanda. Journal of Sustainable Development in Africa, 12, 122-139. 
Vedder, A., Hall, J., Harcourt, A., Monfort, A. \& Wilson, R. (1992) Burundi and Rwanda. In The Conservation Atlas of Tropical Forests: Africa (eds J.A. Sayer, C.S. Harcourt \& N.M. Collins), pp. 102-109. IUCN and Simon and Schuster, New York, USA.

WaAs, P. (1995) Kenya's Indigenous Forests: Status, Management and Conservation. IUCN, Gland, Switzerland.

Weber, W. (1989) An Analysis of Value Conflicts and Convergence in the Management of Afromontane Forests in Rwanda. University of Wisconsin-Madison, Madison, USA.

Wells, M. (1992) Biodiversity conservation, affluence and poverty: mismatched costs and benefits and efforts to remedy them. Ambio, $21,237-243$.

W Under, S. (2007) The efficiency of payments for environmental services in tropical conservation. Conservation Biology, 21, 48-58.

Wunder, S. \& Alban, M. (2008) Decentralized payments for environmental services: the cases of Pimampiro and PROFAFOR in Ecuador. Ecological Economics, 65, 685-698.

\section{Appendices 1-2}

The appendices for this article are available online at http:// journals.cambridge.org

\section{Biographical sketches}

Nicole Gross-CAmP is a tropical ecologist and conservation scientist specializing in the African tropics. AdRIAN MARTIN is a social scientist specializing in research to inform pro-poor management of natural resources in developing countries. SHAWN MCGUiRE's research includes participatory crop breeding, seed systems under stress and farmers' management of genetic resources. BereKet Kebede researches intra-household allocations, social preferences, health, fisheries, land distribution and energy. Joseph Munyarukaza has extensive experience of managing community-based operations in the fields of environment, health, nutrition and emergency relief. 